\title{
SOME EFFECTS OF VARIATION IN SODIUM INTAKE AND OF DIFFERENT SODIUM SALTS IN NORMAL SUBJECTS ${ }^{1}$
}

\author{
By ALEXANDER LEAF, WILLIAM T. COUTER, AND L. H. NEWBURGH \\ (From the Department of Internal Medicine, The Medical School, University of Michigan, \\ Ann Arbor, Mich.)
}

(Received for publication February 25, 1949)

In a separate paper (1) we have described effects resulting from variation of sodium intake in normal subjects, which we attribute to changes in adrenal cortical activity. It is the purpose of this paper to describe some additional effects of considerable physiological interest that were observed in the course of that study.

\section{METHODS}

Three normal young adults were maintained throughout the study on a constant diet adequate in calories and protein with a very low sodium (about $9 \mathrm{mEq}$.) and chloride (about $25 \mathrm{mEq}$.) content. At definite periods $480 \mathrm{mEq}$. of sodium were administered orally daily either as sodium chloride or as sodium citrate. The analytical methods and diet are described in detail in the previous report (1).

\section{RESULTS}

The complete data of this study were presented in a separate paper (1). Only data pertinent to the present discussions will be presented here.

Table I shows the weights of our three normal subjects for the three days before, during and following sodium administration. It is evident that with sodium chloride administration a much more marked gain of weight occurred than with sodium citrate. Each subject was on a maintenance caloric intake so that practically all weight changes occurring over such short periods as these are due to change in body fluid content.

Table II shows the changes in urinary sodium, chloride and potassium excretion that occurred before, during and following each period of sodium administration. No significant changes in fecal sodium, chloride, and potassium were noted and these are not recorded here. It is seen that with administration of sodium chloride there is in each case a parallel increase in both urinary sodium and chloride as would be expected. Following the

1 This study was aided by a grant from the United States Public Health Service. sodium citrate administration a similar increase in sodium excretion is noted; however, chloride excretion remains unchanged, or if anything, slightly decreases.

Table II shows further that with the sodium chloride administration no significant increase in potassium excretion occurred except in the case of M. L., whose urine potassium content rose from about $40 \mathrm{mEq}$. in 24 hours to $88 \mathrm{mEq}$. the first day of sodium chloride administration. In subjects W. C. and E. W. a significant decrease in potassium excretion occurred after cessation of sodium chloride administration. On the first day of sodium citrate administration, a very definite increase in potassium excretion took place in all subjects. This was followed, after omission of sodium citrate, by a decrease to unusually low levels of potassium excretion.

Table III shows the data we have collected re-

TABLE I

Nude, fasting body weights of subjects for the three days before, the three days of sodium administration and the three following days

\begin{tabular}{c|c|c|l}
\hline \hline W. C. & M. L. & E. w. & \\
\hline 75.005 & 68.285 & 64.650 & Low sodium and chloride \\
74.950 & 68.620 & 64.920 & Low sodium and chloride \\
74.565 & 68.640 & 64.805 & Low sodium and chloride \\
76.830 & 70.370 & 66.840 & Sodium chloride 479 mEq. \\
78.250 & 71.480 & 67.500 & Sodium chloride 479 mEq. \\
77.748 & 71.270 & 67.660 & Sodium chloride 479 mEq. \\
74.770 & 70.020 & 66.070 & Low sodium and chloride \\
74.480 & 69.860 & 65.700 & Low sodium and chloride \\
74.100 & 69.480 & 65.400 & Low sodium and chloride \\
\hline 75.750 & 68.650 & 65.230 & Low sodium and chloride \\
75.660 & 68.670 & 64.820 & Low sodium and chloride \\
74.850 & 68.475 & 64.990 & Low sodium and chloride \\
75.370 & 68.901 & 65.440 & Sodium citrate 478 mEq. \\
75.830 & 69.010 & 65.730 & Sodium citrate 478 mEq. \\
75.850 & 68.995 & 66.080 & Sodium citrate 478 mEq. \\
75.330 & 68.650 & 65.340 & Low sodium and chloride \\
75.030 & 68.230 & 65.110 & Low sodium and chloride \\
75.150 & & 65.450 & Low sodium and chloride \\
\hline
\end{tabular}


TABLE II

Urinary sodium, chloride and potassium excretions of subjects for three days before, during, and three days following each three day period of sodium administration

\begin{tabular}{|c|c|c|c|c|c|c|c|c|c|}
\hline \multicolumn{3}{|c|}{ w. C. } & \multicolumn{3}{|c|}{ M. L. } & \multicolumn{3}{|c|}{ E. W. } & \\
\hline $\mathrm{Na}$ & $\mathrm{Cl}$ & $\mathbf{K}$ & $\mathrm{Na}$ & $\mathrm{Cl}$ & $\mathbf{K}$ & $\mathrm{Na}$ & $\mathrm{Cl}$ & $\mathbf{K}$ & \\
\hline $\begin{array}{r}(m E q .) \\
13.2 \\
17.0 \\
1.5\end{array}$ & $\begin{array}{r}(m E q .) \\
5.9 \\
7.0 \\
4.9\end{array}$ & $\begin{array}{r}(m E q .) \\
49.8 \\
49.9 \\
68.2\end{array}$ & $\begin{array}{r}(m E q .) \\
2.6 \\
1.6 \\
1.2\end{array}$ & $\begin{array}{r}(m E q .) \\
2.7 \\
1.0 \\
0.9\end{array}$ & $\begin{array}{r}(m E q .) \\
33.2 \\
42.8 \\
41.2\end{array}$ & $\begin{array}{c}(m E q .) \\
1.9 \\
1.3 \\
0.6\end{array}$ & $\begin{array}{r}(m E q .) \\
15.5 \\
8.7 \\
7.6\end{array}$ & $\begin{array}{r}(m E q .) \\
88.7 \\
103.2 \\
77.1\end{array}$ & $\begin{array}{l}\text { Low sodium and chloride } \\
\text { Low sodium and chloride } \\
\text { Low sodium and chloride }\end{array}$ \\
\hline $\begin{array}{r}20.4 \\
250.2 \\
425.8\end{array}$ & $\begin{array}{r}16.8 \\
267.2 \\
466.8\end{array}$ & $\begin{array}{l}68.2 \\
81.0 \\
83.5\end{array}$ & $\begin{array}{l}152.2 \\
371.2 \\
582.9\end{array}$ & $\begin{array}{l}152.6 \\
411.2 \\
614.4\end{array}$ & $\begin{array}{l}87.6 \\
76.0 \\
41.6\end{array}$ & $\begin{array}{r}72.5 \\
361.6 \\
477.7\end{array}$ & $\begin{array}{l}115.2 \\
395.0 \\
497.0\end{array}$ & $\begin{array}{r}99.2 \\
102.2 \\
62.5\end{array}$ & $\begin{array}{l}\text { Sodium chloride } 479 \mathrm{mEq} \text {. } \\
\text { Sodium chloride } 479 \mathrm{mEq} \text {. } \\
\text { Sodium chloride } 479 \mathrm{mEq} \text {. }\end{array}$ \\
\hline $\begin{array}{r}292.9 \\
53.4 \\
70.5\end{array}$ & $\begin{array}{r}300.7 \\
57.2 \\
63.2\end{array}$ & $\begin{array}{l}78.4 \\
33.8 \\
34.5\end{array}$ & $\begin{array}{r}201.9 \\
53.5 \\
31.0\end{array}$ & $\begin{array}{r}188.4 \\
62.8 \\
42.8\end{array}$ & $\begin{array}{l}30.4 \\
67.6 \\
66.8\end{array}$ & $\begin{array}{r}254.0 \\
108.9 \\
86.0\end{array}$ & $\begin{array}{r}238.5 \\
94.3 \\
87.4\end{array}$ & $\begin{array}{l}47.1 \\
42.8 \\
69.0\end{array}$ & $\begin{array}{l}\text { Low sodium and chloride } \\
\text { Low sodium and chloride } \\
\text { Low sodium and chloride }\end{array}$ \\
\hline $\begin{array}{l}4.2 \\
5.4 \\
7.1\end{array}$ & $\begin{array}{l}14.4 \\
11.2 \\
16.8\end{array}$ & $\begin{array}{l}71.8 \\
79.7 \\
84.4\end{array}$ & $\begin{array}{l}6.4 \\
5.7 \\
4.5\end{array}$ & $\begin{array}{l}8.4 \\
7.8 \\
9.2\end{array}$ & $\begin{array}{l}66.4 \\
60.4 \\
66.4\end{array}$ & $\begin{array}{l}3.72 \\
1.78 \\
2.52\end{array}$ & $\begin{array}{l}25.1 \\
20.7 \\
17.1\end{array}$ & $\begin{array}{r}91.3 \\
103.3 \\
83.4\end{array}$ & $\begin{array}{l}\text { Low sodium and chloride } \\
\text { Low sodium and chloride } \\
\text { Low sodium and chloride }\end{array}$ \\
\hline $\begin{array}{l}284.7 \\
430.9 \\
439.0\end{array}$ & $\begin{array}{l}13.2 \\
10.2 \\
12.0\end{array}$ & $\begin{array}{r}147.6 \\
128.6 \\
66.6\end{array}$ & $\begin{array}{l}305.0 \\
457.5 \\
454.5\end{array}$ & $\begin{array}{l}9.8 \\
6.0 \\
3.5\end{array}$ & $\begin{array}{r}159.6 \\
85.2 \\
78.8\end{array}$ & $\begin{array}{l}214.6 \\
374.7 \\
434.6\end{array}$ & $\begin{array}{l}2.8 \\
5.4 \\
4.1\end{array}$ & $\begin{array}{r}217.7 \\
101.9 \\
58.3\end{array}$ & $\begin{array}{l}\text { Sodium citrate } 478 \mathrm{mEq} \text {. } \\
\text { Sodium citrate } 478 \mathrm{mEq} \text {. } \\
\text { Sodium citrate } 478 \mathrm{mEq} \text {. }\end{array}$ \\
\hline $\begin{array}{r}112.7 \\
50.1 \\
26.0\end{array}$ & $\begin{array}{l}9.6 \\
9.6 \\
6.2\end{array}$ & $\begin{array}{l}40.0 \\
31.2 \\
53.6\end{array}$ & $\begin{array}{l}61.1 \\
66.3\end{array}$ & 3.0 & $\begin{array}{r}9.2 \\
20.4\end{array}$ & $\begin{array}{r}188.2 \\
71.4 \\
25.9\end{array}$ & $\begin{array}{l}6.7 \\
8.3 \\
8.6\end{array}$ & $\begin{array}{l}22.0 \\
32.2 \\
52.7\end{array}$ & $\begin{array}{l}\text { Low sodium and chloride } \\
\text { Low sodium and chloride } \\
\text { Low sodium and chloride }\end{array}$ \\
\hline
\end{tabular}

garding glomerular filtration rate and sodium and chloride excretion in these normal subjects. In subject $\mathrm{E}$. W. the glomerular filtration rate is estimated from the 24 hour endogenous creatinine clearance $(2,3)$. In our other two subjects, glomerular filtration rate was determined by inulin clearances (4). The sodium and chloride excretions were obtained simultaneously with the filtration rates.

\section{DISCUSSION}

The discussion is organized about the four points we wish to stress :

\section{The importance of fixed anion as well as cation to the accumulation of extracellular fluid.}

As is well known, quantitatively the important cation of the extracellular fluids is sodium, and through renal regulation the concentration of sodium in the extracellular fluids is maintained within very narrow limits. Even in disease it is uncommon to find the serum sodium concentration varying more than $20 \mathrm{mEq}$./L from the normal value of about $140 \mathrm{mEq}$. Thus, it has come to be generally realized that extracellular fluid volume does not increase without available sodium
(5). This fact has become the central principle in the management of clinical edema by sodium restriction.

Furthermore it is true that the important anion of the extracellular fluid regarded quantitatively is chloride. Little, however, is mentioned regarding the role played by chloride in the accumulation of extracellular fluid. Table I and Figure 1, which show the changes in body weight that occurred with administration of equivalent amounts of sodium first as sodium chloride and then as sodium citrate, clearly indicate that weight gain is much greater following administration of sodium chloride. In short experiments of this type, change in weight is necessarily due almost entirely to changes in body fluid content. Calculation of predicted weight change from increase in chloride space following sodium chloride administration reveals that the weight gain is almost entirely due to increase in extracellular fluid. Figure 1 shows that the serum sodium and chloride concentrations in subject $\mathrm{E}$. W. rose slightly and equally on administration of sodium chloride.

The inability to accumulate much extracellular fluid and gain weight when the same amount of sodium was administered as the citrate salt was 
TABLE III

Simultaneous glomerular filtration rate and urine sodium and chloride excretions

\begin{tabular}{|c|c|c|c|c|c|}
\hline & Experimental day & $\begin{array}{l}{ }^{* G l o m e r u l a r} \\
\text { filtration }\end{array}$ & Urinary sodium & Urinary chloride & \\
\hline \multirow{5}{*}{ Subject E. W. } & $\begin{array}{l}1 \\
5 \\
8\end{array}$ & $\begin{array}{c}L / 24 \text { hrs.* } \\
165 \\
157 \\
165\end{array}$ & $\begin{array}{c}m E q . / 24 \text { hrs. } \\
94 \\
2.0 \\
0.6\end{array}$ & $\begin{array}{l}m E q . / 24 \text { hrs. } \\
114 \\
15.2 \\
7.6\end{array}$ & $\begin{array}{l}\text { Low } \mathrm{Na} \text { and } \mathrm{Cl} \\
\text { Sodium-9.4 mEq. } \\
\text { Chloride-24.9 mEq. } \\
\text { Daily }\end{array}$ \\
\hline & $\begin{array}{r}9 \\
10 \\
11\end{array}$ & 160 & 72.5 & 115 & $\begin{array}{l}\text { High } \mathrm{Na} \text { and } \mathrm{Cl} \\
\text { Sodium-488 mEq. } \\
\text { Chloride- }-504 \mathrm{mEq} \text {. } \\
\text { Daily }\end{array}$ \\
\hline & $\begin{array}{l}12 \\
15 \\
17\end{array}$ & $\begin{array}{l}192 \\
133 \\
153\end{array}$ & $\begin{array}{r}254 \\
31.6 \\
1.8\end{array}$ & $\begin{array}{l}239 \\
55.3 \\
20.7\end{array}$ & $\begin{array}{l}\text { Low } \mathrm{Na} \text { and } \mathrm{Cl} \\
\text { Sodium }-9.4 \mathrm{mEq} \text {. } \\
\text { Chloride }-24.9 \mathrm{mEq} \text {. } \\
\text { Daily }\end{array}$ \\
\hline & $\begin{array}{l}19 \\
20 \\
21\end{array}$ & 161 & 215 & 2.8 & $\begin{array}{l}\text { High Na citrate } \\
\text { Sodium-488 } \mathrm{mEq} . \\
\text { Chloride- }-24.9 \mathrm{mEq} . \\
\text { Daily }\end{array}$ \\
\hline & $\begin{array}{l}22 \\
25 \\
29 \\
32\end{array}$ & $\begin{array}{l}161 \\
160 \\
155 \\
149 \\
\end{array}$ & $\begin{array}{r}188 \\
15.0 \\
3.0 \\
7.0 \\
\end{array}$ & $\begin{array}{r}6.7 \\
9.4 \\
13.3 \\
19.3 \\
\end{array}$ & $\begin{array}{l}\text { Low } \mathrm{Na} \text { and } \mathrm{Cl} \\
\text { Sodium-9.4 mEq. } \\
\text { Chloride-24.9 mEq. } \\
\text { Daily }\end{array}$ \\
\hline \multirow{2}{*}{ Subject W. C. } & 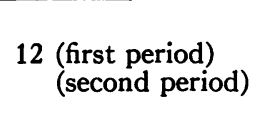 & $\begin{array}{c}\text { ml./min.** } \\
121 \\
113\end{array}$ & $\begin{array}{c}m E q . / m i n \\
0.020 \\
0.018\end{array}$ & $\begin{array}{c}m E q . / m i n \\
0.017 \\
0.011\end{array}$ & $\begin{array}{c}\text { Low } \mathrm{Na} \text { and } \mathrm{Cl} \\
\text { (as above) }\end{array}$ \\
\hline & $\begin{array}{l}25 \text { (first period) } \\
\text { (second period) }\end{array}$ & $\begin{array}{l}156 \\
159\end{array}$ & $\begin{array}{l}1.56 \\
1.07\end{array}$ & $\begin{array}{l}1.29 \\
1.07\end{array}$ & $\begin{array}{l}\text { High } \mathrm{Na} \text { and } \mathrm{Cl} \\
\text { (as above) }\end{array}$ \\
\hline \multirow{3}{*}{ Subject M. L. } & 9 (first period) & $\begin{array}{l}117 \\
124\end{array}$ & $\begin{array}{l}0.098 \\
0.17\end{array}$ & $\begin{array}{l}0.093 \\
0.16\end{array}$ & $\begin{array}{c}\text { Low } \mathrm{Na} \text { and } \mathrm{Cl} \\
\text { (as above) }\end{array}$ \\
\hline & 17 (first period) & $\begin{array}{l}126 \\
119\end{array}$ & $\begin{array}{l}0.53 \\
0.71\end{array}$ & $\begin{array}{l}0.46 \\
0.67\end{array}$ & $\begin{array}{c}\text { High } \mathrm{Na} \text { and } \mathrm{Cl} \\
\text { (as above) }\end{array}$ \\
\hline & $\begin{array}{l}29 \text { (first period) } \\
\text { (second period) }\end{array}$ & $\begin{array}{l}113 \\
111\end{array}$ & $\begin{array}{l}0.081 \\
0.216\end{array}$ & $\begin{array}{l}0.024 \\
0.016\end{array}$ & $\begin{array}{l}\text { High Na citrate } \\
\text { (as above) }\end{array}$ \\
\hline
\end{tabular}

* Glomerular filtration rate was determined as the 24 hour endogenous creatinine clearance in subject E. W.

** Glomerular filtration rate was determined as the inulin clearance in subjects W. C. and M. L.

apparently due to the lack of fixed anion, specifcally chloride. Since the citrate anion is metabolized in the body it leaves the sodium cation without an accompanying fixed anion. Classical studies have shown that when sodium enters the extracellular fluid compartment without equivalent fixed anion it becomes largely associated with bicarbonate, equivalent for equivalent, keeping the total cation and anion concentrations of the extracellular fluids equal. Such an increase in bicarbonate concentration tends to produce an alkalosis (rise in $\mathrm{pH}$ above the normal value 7.35 ) in the extracellular fluids. The magnitude of this disturbance is diminished by removal of sodium from the extracellular fluid by renal excretion and by its entry into the intracellular compartment. The extent to which these two regulatory mechanisms failed to prevent a temporary increase in bicarbonate concentration in the extracellular fluid of $\mathrm{E}$. W. is indicated in Figure 1 by the rise in serum sodium from 138.6 to $144.9 \mathrm{mEq}$. per liter and drop in serum chloride from 97.6 to $95.6 \mathrm{mEq}$. per liter that occurred with the sodium citrate administration. The serum $\mathrm{CO}_{2}$ content rose from 30.3 to $37.3 \mathrm{mM}$ per liter. As the low chloride intake had already resulted in very small amounts of chloride in the urine, the kidneys were unable to make fixed anion available in significant amounts 
by any further reduction in urine chloride excretion. The slight weight gain that occurred was associated with the small expansion of extracellular fluid volume made permissible by the dilution of the existing chloride content of the extracellular fluid. Thus in the absence of fixed anion, administration of sodium, even in large amounts, does not increase extracellular fluid volume importantly.
II. Dissociation of renal sodium and chloride excretion

Table II clearly shows that when sodium chloride is administered there occurs a parallel increase in urinary excretion of sodium and chloride. With the administration of sodium citrate a similar increase in urinary sodium occurs but the urinary chloride continues to be small or even

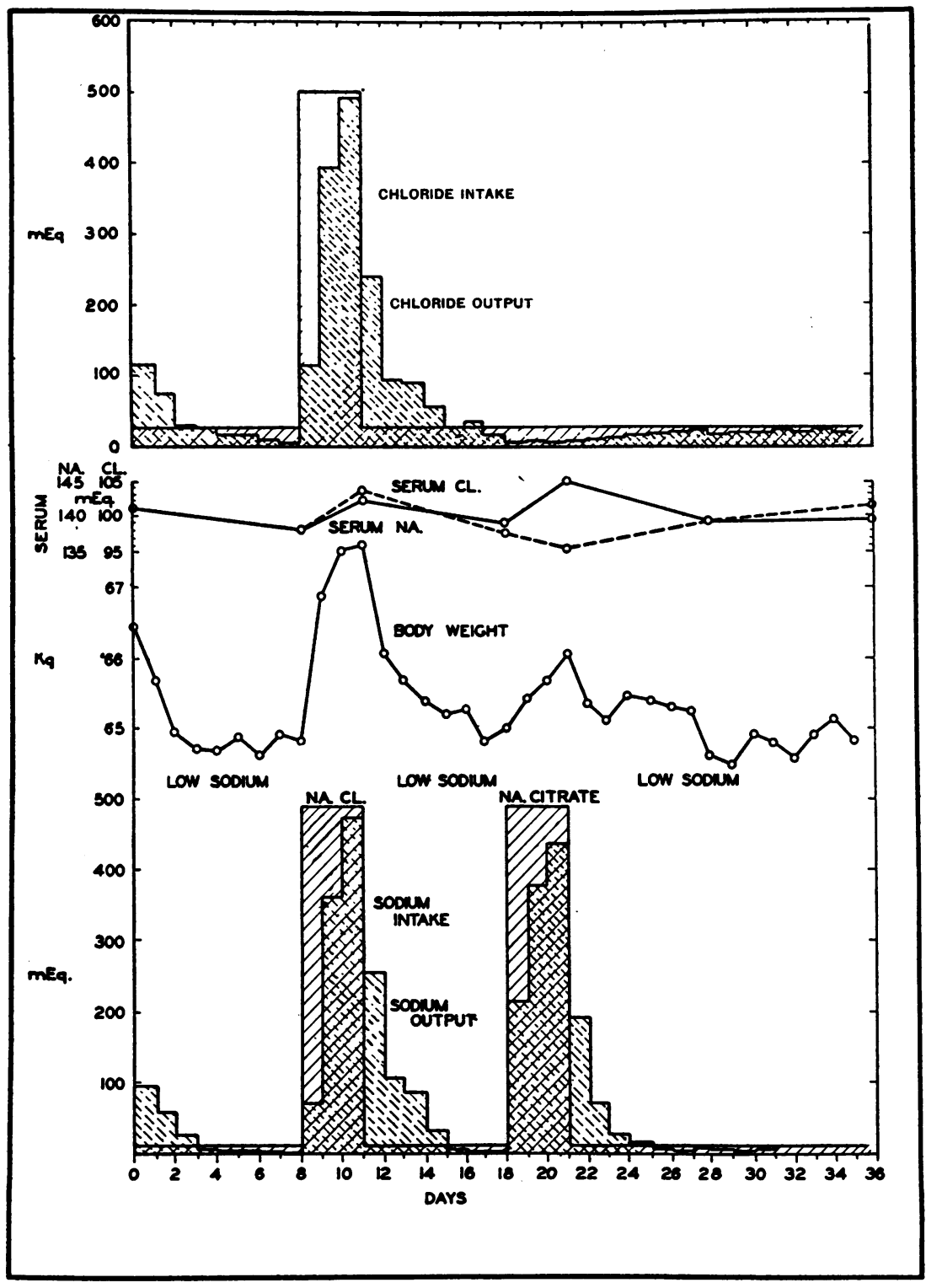

Fig. 1. To Show Changes in Body Weight, Serum Sodium and Chloride Concentrations Together with Sodium (Lower) and Chloride (Upper) Balances in Subject E. W.

Note especially the decreased chloride excretions occurring during the period of sodium citrate administration. 
decreases below the base line. This is illustrated in Figure 1 for subject E. W.

In another report (1) we present evidence to support the belief that the renal excretion of sodium in normal human subjects is regulated by adrenal cortical activity. Earlier studies by others of the action of adrenal cortical extracts and adrenal cortical hormones on sodium and chloride balance suggested a similar effect on both sodium and chloride $(6-8)$. Such studies in the past have been conducted under conditions that might be expected to cause parallel changes in sodium and chloride balance, i.e., loss of sodium and chloride in the urine following adrenalectomy and retention of sodium and chloride on administration of adrenal cortical extract or adrenal cortical steroids to adrenalectomized animals. But when a definite need on the part of the body to conserve fixed anion, chiefly chloride, is created because of the presence of a large excess of sodium cation, a complete dissociation in the renal excretion of sodium and chloride is elicited. Our earlier studies (1) indicate that large intakes of sodium, either as the chloride or citrate salts, depress adrenal cortical activity. This would permit the large urinary excretion of sodium that followed the administration of sodium citrate; but accompanying this extensive removal of sodium there is no increased loss of chloride. In fact the urinary values for chloride fell below those of the control period. What it is that causes the kidneys to conserve chloride when excess base is administered, this study does not indicate. It is recognized, however, that such reduction of renal excretion of chloride serves a useful function in conserving fixed anion in the presence of the threat of alkalosis resulting from the sodium citrate administration- another example of the "wisdom" of the body.

\section{Displacement of intracellular potassium by sodium}

It was noted that each of our subjects showed a prompt and striking increase in urinary potassium excretion during the first 24 hours of sodium citrate administration. By the third day of the sodium citrate period the urinary potassium had dropped to or below the base line (see Table II). No such increase in urinary potassium content occurred with sodium chloride administration ex- cept possibly for the much less striking increase in subject M. L. Figure 2 shows the theoretical potassium balance calculated from the actual nitrogen balance (grams nitrogen balance $\times 2.7=$ $\mathrm{mEq}$. theoretical potassium balance on the basis of changes in body protoplasm) and indicates that this potassium excretion was not the result of increased catabolism of tissues. Figure 2 also clearly shows that this marked potassium diuresis coincided with the markedly positive balance of sodium unaccompanied by fixed anion that resulted from the sodium citrate administration.

To learn more about the association of positive sodium and negative potassium balance the calculations shown in Table IV were made according to the method of Darrow (9) for the periods of sodium administration in each subject. The extracellular fluid volume was estimated as $20 \%^{2}$ of the body weight on the morning of the first day of sodium administration. It is seen from Table IV that in each case with sodium citrate administration there is a positive intracellular sodium balance, definite in E. W. (222 mEq.) and M. L. (178 $\mathrm{mEq}$.) and perhaps equivocal in subject W. C. (83 mEq.). This is associated with a negative

2 Recent evidence by inulin space determinations (20) indicates that the extracellular. fluid volume may be less than this per cent. Our subjects also had some shrinkage of extracellular volume as a result of the preceding restriction of sodium and chloride intake. However, the value taken for the initial extracellular fluid volume in these calculations, within reasonable limits, only insignificantly affects the results.

TABLE IV

Changes in intracellular sodium and potassium balances that occurred during the three-day periods of sodium chloride and sodium citrate administration *

\begin{tabular}{|c|c|c|c|c|c|c|}
\hline & $\begin{array}{c}\text { Total } \\
\mathrm{Na} \\
\text { balance }\end{array}$ & $\begin{array}{c}\text { Total } \\
\mathrm{K} \\
\text { balance }\end{array}$ & $\begin{array}{l}\text { Extra- } \\
\text { cell-Na } \\
\text { balance }\end{array}$ & $\begin{array}{c}\text { Extra- } \\
\text { cell-K } \\
\text { balance }\end{array}$ & $\begin{array}{l}\text { Intra- } \\
\text { cell-Na } \\
\text { balance }\end{array}$ & $\begin{array}{l}\text { Intra- } \\
\text { cell-K } \\
\text { balance }\end{array}$ \\
\hline $\begin{array}{r}\text { Subject } E . W . \\
\text { after } \mathrm{NaCi} \\
\text { after } \mathrm{NaCit} .\end{array}$ & $\begin{array}{l}m E q . \\
+553 \\
+436\end{array}$ & $\begin{array}{r}m E q \\
-9 \\
-108\end{array}$ & $\begin{array}{l}m E q . \\
+644 \\
+214\end{array}$ & $\begin{array}{r}m E q . \\
+13 \\
+2\end{array}$ & $\begin{array}{r}m E q . \\
-91 \\
+222\end{array}$ & $\begin{array}{l}m E q . \\
-22 \\
-110\end{array}$ \\
\hline $\begin{array}{l}\text { Subject } M . L . \\
\text { af ter } \mathrm{NaCl} \\
\text { after } \mathrm{NaCit} .\end{array}$ & $\begin{array}{l}+355 \\
+236\end{array}$ & $\begin{array}{l}+46 \\
-76\end{array}$ & $\begin{array}{r}+401 \\
+58\end{array}$ & $\begin{array}{r}+11 \\
+3\end{array}$ & $\begin{array}{r}-46 \\
+178\end{array}$ & $\begin{array}{l}+35 \\
-79\end{array}$ \\
\hline $\begin{aligned} & \text { Subject } W . C . \\
& \text {. after } \mathrm{NaCl} \\
& \text { after } \mathrm{NaCit} .\end{aligned}$ & $\begin{array}{r}+759 \\
+303\end{array}$ & $\begin{array}{r}-60 \\
-133\end{array}$ & $\begin{array}{l}+722 \\
+220\end{array}$ & 0 & $\begin{array}{l}+37 \\
+83\end{array}$ & -133 \\
\hline
\end{tabular}

* The complete data from which these calculated values were derived are presented in our preceding paper (1). 


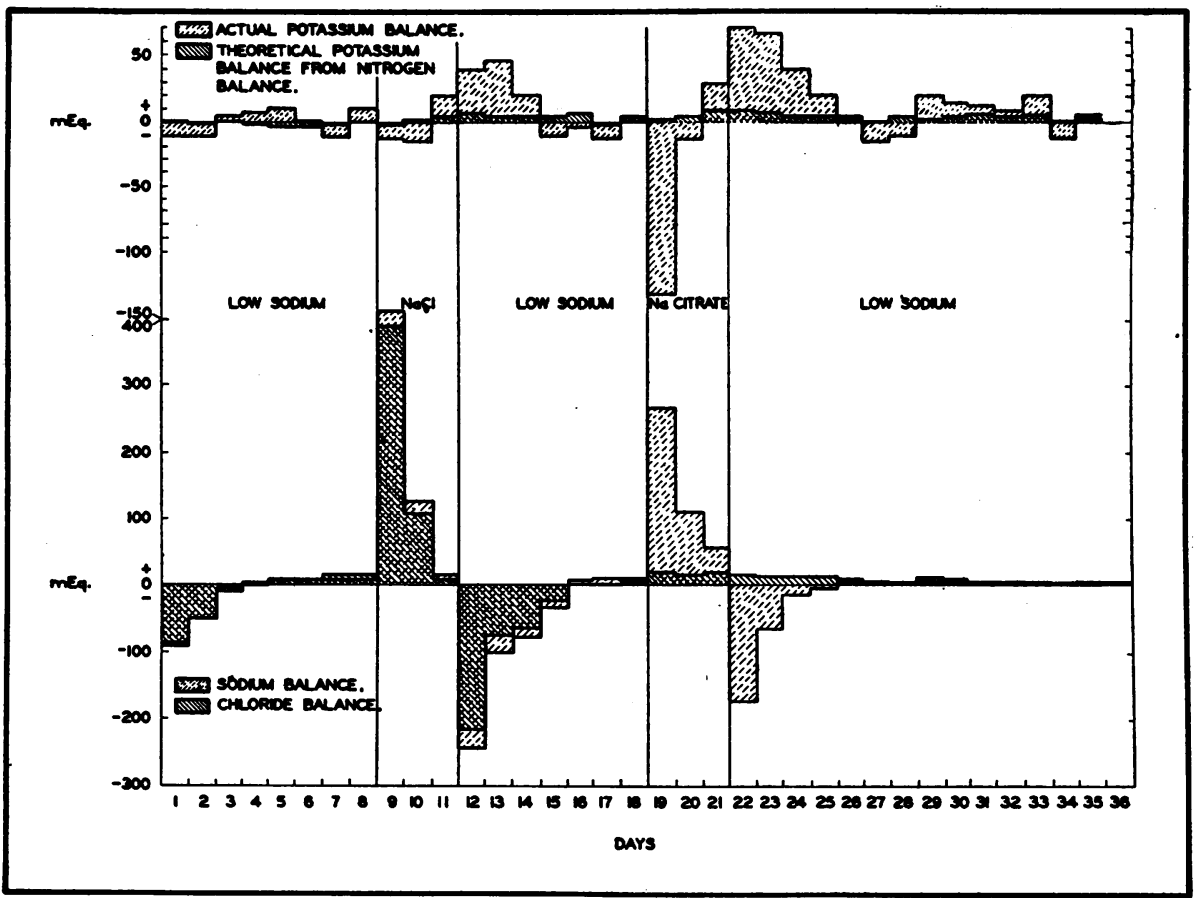

Fig. 2. The Actual and Theoretical Potassium Balances (Upper) and Sodium and Chloride Balances (Lower) in Subject E. W.

Note that the sodium and chloride balances change together except during and following the period of sodium citrate administration. The factor 2.7 was used to convert grams of observed nitrogen balance to milli-equivalents of "theoretical potassium balance." The values plotted are the difference between intake and urine plus fecal excretions. Note the large negative potassium balance during the first day of sodium citrate administration.

intracellular potassium balance of $-110,-79$, and $-133 \mathrm{mEq}$. respectively for the three-day period.

This method of calculation originated by Darrow is based on the assumption that nearly all of the chloride of the body is restricted to the extracellular fluid compartment. The significant positive figures for "intracellular sodium balance" (or sodium that cannot be accounted for in the extracellular fluids of the body) clearly indicate that sodium has entered some part of the body unaccompanied by chloride. The coincident strongly negative potassium balance is good evidence that this sodium entered the intracellular compartment without chloride, displacing potassium, in so doing. We make no attempt to quantitate the intracellular sodium gain with the potassium loss, as extraneous factors, such as increase in tonicity of the extracellular fluid that occurred with the sodium administration and which might require changes in the total cation concentration within the cells, invalidate such attempts.
Administration of the sodium cation with fixed anion as sodium chloride resulted in no such gain in intracellular sodium. The total gain in body sodium was associated with nearly an equivalent gain of chloride. The sodium gain was accounted for by the increase in chloride space-expanded extracellular fluid volume. There was no occasion for sodium to pass into the cells. Hence no displacement of potassium occurred.

These findings, namely, displacement of intracellular potassium on administration of sodium citrate, ${ }^{3}$ strongly support the excellent studies of Darrow $(8,10-13)$ that the intracellular sodium plays a role in the defense of the normal extracellular $\mathrm{pH}$.

The data presented in the preceding publication (1) offer an explanation of the lag in excretion of sodium on changing from low to high intake

3 One may anticipate exactly similar effects from sodium bicarbonate, acetate, lactate or other sodium salts having an associated anion that will be metabolized to bicarbonate in the body. 
of sodium. Namely that the sharp restriction of sodium just before the administration of sodium citrate, resulted in maximal reabsorption of sodium in response to augmented adrenal cortical activity. This effect in decreasing amounts was continued for several days after the subjects had begun to take the sodium citrate. Thereafter, the adrenal drive relaxed and the large intake of sodium was accompanied by a plentiful excretion of sodium. During this lag in renal adjustment, the sodium cation passed into the cells of the body from the extracellular fluids, without accompanying fixed anion. This reduced the "available base" (or $\mathrm{CO}_{2}$ content) of the extracellular fluids, and hence the extent of alkalosis that would have otherwise been produced by the sodium citrate administration. Had this shift of sodium into the cells failed to occur in subjects E. W. and M. L. an increase in the extracellular $\mathrm{CO}_{2}$ content of 15 and $12 \mathrm{mM}$ per liter, respectively, might have occurred with a resultant severe alkalosis.

The renal excretion of the potassium displaced from the cells was not impeded by the augmented adrenal cortical activity as was the sodium, since the potassium appeared in the urine. Desoxycorticosterone, the adrenal cortical salt-and-waterhormone par excellence, facilitates renal excretion of potassium while decreasing renal excretion of sodium (14). Hence the adrenal cortical activity during the lag in adjustment to the high sodium intake, though it prevented renal excretion of sodium, perhaps facilitated renal excretion of potassium. In subject E. W. the urine collection during the first 24 hours of sodium citrate administration was divided so that the urine passed during the first six hours of sodium citrate administration was collected separately and on analysis was found to contain only $1.4 \mathrm{mEq}$. of sodium (out of a total excretion of $215 \mathrm{mEq}$. for that 24 hour period) while it contained more than one-fourth of the total large potassium excretion of that day.

The negative intracellular sodium balance that followed the sodium chloride administration in subject $E$. W. is of sufficient magnitude to be interesting. The administration of large amounts of sodium chloride, which is "acid-producing" in that it contains equivalents of sodium and chloride (whereas the extracellular fluids normally contain sodium to chloride in the ration of 1.4 to 1 ), apparently caused a transfer of intracellular so- dium to the extracellular fluids which would serve to help combat this effect of sodium chloride administration. Such a mechanism assisting in the prevention of acidosis has also been described by Darrow $(11,15)$.

It is realized that the type of calculation made above would include any extrarenal or extrafecal sodium loss from the body as a gain in "intracellular sodium." This possibility reduces itself to losses of sodium through the skin. The studies of Freyberg and Grant (16) of the insensible losses of sodium from the skin of normal adult subjects show that the daily sodium loss is less than $10 \mathrm{mEq}$. Hence in our normal subjects who avoided exertion and sweating, a cumulative loss of sodium through the skin over the three-day periods of about $30 \mathrm{mEq}$. would scarcely affect the positive balances recorded.

\section{Glomerular filtration, tubular reabsorption and the excretion of sodium}

There has been considerable discussion in the current literature regarding the possible roles played by change in glomerular filtration rate and tubular reabsorption of sodium in the formation of edema (17-19). Because our studies involved very low and very high rates of sodium and chloride excretion resulting from the marked variations in sodium intake, observations were made to determine, if possible, how glomerular filtration and tubular reabsorption of sodium affected the excretion of sodium by normal subjects. Table III shows the simultaneous 24 hour endogenous creatinine clearance taken as a measure of glomerular filtration rate $(2,3)$ and the simultaneous 24 hour urine sodium and chloride content. Simultaneous inulin clearances and sodium excretions for subjects M. L. and W. C. are also recorded.

It is obvious from a brief examination of these data that there is no correlation between glomerular filtration rate and renal excretion of sodium or chloride. Following the sodium chloride administration an increase in glomerular filtration rate is associated with an increased rate of excretion of sodium. However, no such increased rate is seen following the sodium citrate administration in spite of an equally large increase in the rate of sodium excretion. In another paper (1) we have suggested that the increased glomerular filtration rate 
following sodium chloride administration is a nonspecific response secondary to the resulting increased vascular volume. One certainly is not justified in interpreting it as a specific adjustment of the kidney for the purpose of increasing sodium excretion as has been postulated recently (18). Our findings in normal subjects are similar to those of Briggs et al. (19) who found no relation between glomerular filtration rates and sodium excretion in patients with congestive heart failure.

In what has just been said, mention of the serum sodium and chloride concentrations at the time of these clearance studies has been purposely avoided. Mokotoff et al. (18) have claimed that the tubular reabsorption of sodium is constant per unit of glomerular filtrate volume (" $13.3 \mathrm{mM}$ per $100 \mathrm{cc}$. of glomerular filtrate") and therefore varies directly with the glomerular filtration rate. These workers subtracted the sodium excreted in the urine from the product of the glomerular filtration rate and the serum sodium to obtain the rate of tubular reabsorption. As the quantity of sodium filtered is in nearly all cases tremendous in comparison with the quantity excreted such calculations are questionable. With a glomerular filtration rate of 160 liters in 24 hours and serum sodium of $140 \mathrm{mEq}$. per liter our subject $\mathrm{E}$. W. was presenting approximately $22,400 \mathrm{mEq}$. of sodium to his renal tubules while the 24 hour urinary sodium excretion varied between 0.6 and $500 \mathrm{mEq}$. depending on the sodium intake. Thus as some $97 \%$ of the filtered sodium was always reabsorbed, the relatively large shift in urinary sodium must have occurred as a result of variations within this remaining $3 \%$ of the filtered sodium. In edematous cardiac and nephritic patients the glomerular filtration rate, though somewhat reduced (17-19), remains sufficiently large to still make the quantity of sodium excreted only a very small percentage of that filtered. Accordingly, the answer to the whole problem of the manner in which renal function is altered in certain cardiac and nephritic subjects making them unable to rid themselves of the usual daily sodium intake is hidden in the manner in which this very small fraction of the total filtered sodium is handled. However, methods such as the mannitol clearance with its unavoidable error of about $10 \%$ are much too crude to demonstrate these fine changes. One cannot detect changes of $3 \%$ in a function by using a measuring stick with a $10 \%$ error.

\section{CONCLUSIONS}

Sodium as the chloride and as the citrate salts was administered to normal subjects maintained on very low sodium and chloride diets. The effects on body weight, sodium, potassium, chloride and nitrogen balances were recorded. Simultaneous glomerular filtration rates and urinary excretions of sodium and chloride were obtained.

The gain in body weight with sodium chloride was strikingly greater than with sodium citrate. Ingestion of sodium as chloride caused parallel increases in urinary excretion of sodium and chloride, whereas sodium as citrate resulted in a similar increase in urinary sodium but the urinary chloride did not increase. Since in the previous paper (1) it was concluded that the desoxycorticosterone-like hormone activity of the adrenal cortex is depressed by sodium administration, this dissociation of sodium and chloride excretion demonstrates that some other factor causes renal conservation of chloride.

When sodium was administered as the citrate salt, a large increase in body sodium occurred accompanied by a large diuresis of potassium. Appropriate calculations indicate that significant amounts of sodium entered the cells, displacing large amounts of potassium.

The quantities of sodium appearing in the urine from 0.6 to $4.77 \mathrm{mEq}$. bore no relationship to the simultaneous volumes of glomerular filtrate. The sodium present in the urine is $3 \%$ or less of the sodium delivered to the tubules in the glomerular filtrate. Accordingly the relatively small variation in the amount of sodium not reabsorbed determines whether body sodium will be increased or decreased. Since the error inherent in the present methods is greater than the function to be measured, the exact role of filtration rate and tubular reabsorption in the excretion of sodium cannot at the present time be defined.

\section{ACKNOWLEDGMENTS}

The authors wish especially to thank Drs. Augusto Camara and Vivian Iob, Miss Barbara Stone, and Mrs. Clara Noble for their invaluable technical assistance during this study. 


\section{BIBLIOGRAPHY}

1. Leaf, A., and Couter, W. T., Evidence that renal sodium excretion by normal human subjects is regulated by adrenal cortical activity. J. Clin. Invest., 1949, 28, 1067.

2. Steinitz, K., and Turkand, H., The determination of the glomerular filtration rate by the endogenous creatinine clearance. J. Clin. Invest., 1940, 19, 285.

3. Brod, J., and Sirota, J. H., The renal clearance of endogenous "creatinine" in man. J. Clin. Invest., 1948, 27, 645.

4. Golding, W., and Chasis, H., Hypertension and $\mathrm{Hy}-$ pertensive Disease. Commonwealth Fund, New York, 1944, p. 198.

5. Newburgh, L. H., and MacKinnon, F., The Practice of Dietetics. The Macmillan Company, New York, 1933, p. 240.

6. Loeb, R. F., Atchley, D. W., Benedict, E. M., and Leland, J., Electrolyte balance studies in adrenalectomized dogs with particular reference to the excretion of sodium. J. Exper. Med., 1933, 57, 775.

7. Thorn, G. W., Garbutt, H. R., Hitchcock, F. A., and Hartman, F. A., The effect of cortin upon the renal excretion of sodium, potassium, chloride, inorganic phosphorus and total nitrogen in normal subjects and in patients with Addison's disease. Endocrinology, 1937, 21, 213.

8. Forsham, P. H., Thorn, G. W., Bergner, G. E., and Emerson, K., Jr., Metabolic changes induced by synthetic 11-dehydrocorticosterone acetate. Am. J. Med., 1946, 1, 105.

9. Darrow, D. C., The retention of electrolyte during recovery from severe dehydration due to diarrhea. J. Pediat., 1946, 28, 515.
10. Darrow, D. C., Congenital alkalosis with diarrhea. J. Pediat., 1945, 26, 519.

11. Darrow, D. C., da Silva, M. M., and Stevenson, S. S., Production of acidosis in premature infants by protein milk. J. Pediat., 1945, 27, 43.

12. Darrow, D. C., Changes in muscle composition in alkalosis. J. Clin. Invest., 1946, 25, 324.

13. Darrow, D. C., Schwartz, R., Iannucci, J. F., and Coville, F., The relation of serum bicarbonate concentration to muscle composition. J. Clin. Invest., 1948, 27, 198.

14. Thorn, G. W., Desoxycorticosterone. J. Mt. Sinai Hospital, 1942, 8, 1177.

15. Darrow, D. C., Disturbances in electrolyte metabolism in man and their management. Bull. New York Acad. Med., 1948, 24, 147.

16. Freyberg, R. H., and Grant, R. L., Loss of minerals through the skin of normal humans when sweating is avoided. J. Clin. Invest., 1937, 16, 720.

17. Merrill, A. J., Edema and decreased renal blood flow in patients with chronic congestive heart failure. J. Clin. Invest., 1946, 25, 389.

18. Mokotoff, R., Ross, G., and Leiter, L., Renal plasma flow and sodium reabsorption and excretion in congestive heart failure. J. Clin. Invest., 1948, 27, 1.

19. Briggs, A. P., Fowell, D. M., Hamilton, W. F., Remington, J. W., Wheeler, N. C., and Winslow, J. A., Renal and circulatory factors in the edema formation of congestive heart failure. J. Clin. Invest., 1948, 27, 810.

20. Gaudino, M., Schwartz, I. L., and Levitt, M. F., Inulin volume of distribution as a measure of extracellular fluid in dog and man. Proc. Soc. Exper. Biol. \& Med., 1948, 68, 507. 